\title{
The etiological agent of cotton ramulosis represents a single phylogenetic lineage within the Colletotrichum gloeosporioides species complex
}

\author{
Maria Eloisa Salustiano, Marina Nunes Rondon, Lucas M. Abreu, Sarah da Silva Costa, José da Cruz \\ Machado \& Ludwig H. Pfenning
}

Departamento de Fitopatologia, Universidade Federal de Lavras, Lavras MG, Brazil

Author for correspondence: Ludwig H. Pfenning, e-mail: ludwig@dfp.ufla.br

\begin{abstract}
Ramulosis of cotton, caused by Colletotrichum gossypii var. cephalosporioides (CGC), is an important disease of cotton in Brazil. The main objective of this work was to test whether CGC is a phylogenetic species inside the Colletotrichum gloeosporioides species complex. A Bayesian inference phylogenetic analysis of a combined ITS and TUB2 dataset was conducted with 21 strains identified as CGC and five strains of Colletotrichum gossypii (CG), associated with cotton anthracnose, obtained from diseased plants from different regions of Brazil. All CGC strains formed a highly supported lineage inside the clade of Colletotrichum theobromicola, a member of the C. gloeosporioides species complex. CG strains formed another lineage in the same clade. These findings were supported by a second analysis conducted with three genes (ITS+TUB2+GAPDH) and a subset of five CGC and three CG strains. During pathogenicity tests, all five CGC strains tested induced typical symptoms of ramulosis on inoculated plants, including foliar necrosis, death of apical meristems and over sprouting. Plants inoculated with CG strains exhibited foliar necrotic spots two months after inoculation. These results give phylogenetic support for the placement of CGC in the C. gloeosporioides species complex, and the distinction between the ramulosis and anthracnose pathogens of cotton in Brazil.
\end{abstract}

Key words: Colletotrichum theobromicola, Gossypium hirsutum, anthracnose, escobilla of cotton, seed transmitted pathogen.

\section{INTRODUCTION}

Ramulosis is one of the most important diseases of cotton (Gossypium hirsutum) in Brazil, and occurs in all major producing areas of the country (Silva-Mann et al., 2005). The disease is also known in Paraguay and Venezuela (Malaguti, 1955; Mathieson \& Mangano, 1985), and may be present elsewhere in South America. Initial disease symptoms are circular spots on young leaves that cause crisping of the surface, usually near the midrib, and posterior development of star-shaped perforations in the leaf blades. The fungus kills the apical meristems and induces abnormal sprouting of lateral buds on affected branches, resulting in clusters of branches with short, swollen internodes (Araújo et al., 2003; Saran, 2009). Ramulosis was first described in 1937 in cotton farms in São Paulo state by Costa \&Fraga Jr. (1937), and its etiological agent described as Colletotrichum gossypii var. cephalosporiodes (Costa \& Fraga Jr., 1939). At this time, it was considered a more aggressive form of C. gossypii, a previously described cotton pathogen in the USA (Atkinson, 1891; Southworth,1890). In 1946, Viegas validated the name of this variety, providing a Latin description and denoting a type (Viegas, 1946). Ever since, this name has been widely applied to the pathogen causing ramulosis of cotton in Brazil (Kirkpatrick \& Rothrock, 2001; Monteiro et al., 2009; Silva-Mann et al., 2005).

Anthracnose of cotton is a disease involving damping-off and death of seedlings, as well as symptoms of necrosis on leaves, stems, and bolls (Kirkpatrick \& Rothrock, 2001). In Brazil, the anthracnose pathogen is mainly regarded as a damping-off agent and a minor foliar pathogen in the end of the vegetative cycle (Silva-Mann et al., 2005). The ramulosis and anthracnose pathogens are supposed to be seed transmitted (Lima et al., 1985). The proposed tolerance level for the ramulosis pathogen on commercial cotton seed is zero, as defined by the Brazilian phytosanitary authority (MAPA, 2005). Colletotrichum gossypii is also of quarantine importance in Europe (EPPO, 2009). Blotter tests are used routinely to detect the ramulosis pathogen on seeds (Tanaka et al., 1996); however, morphological markers of the cultures from the blotter tests do not suffice for reliable identification within the current species concept in Colletotrichum (Cai et al., 2009, 2011; Cannon et al., 2012). Due to the economic importance of ramulosis, and the apparent restricted biogeographical distribution of its etiological agent, improved quarantine legislation and disease risk assessment depend on the correct identification of the 
pathogen based on molecular phylogenetics (Cai et al., 2011).

In Brazil, ramulosis and anthracnose appear to be caused by two distinct pathogens that belong to the Colletotrichum gloeosporioides species complex (Bailey et al., 1996; Silva-Mann et al., 2005). This complex is composed of species that share common morphological traits and form a strongly supported monophyletic group, as determined by independent studies (Cai et al., 2011; Cannon et al., 2012; Weir et al., 2012). Multilocus phylogenies, inferred from DNA sequences of reference strains and newly collected isolates from different hosts and geographic regions, allowed the recent recognition of more than 20 phylogenetic species inside the $C$. gloeosporioides species complex (Weir et al., 2012). Due to the lack of DNA sequences from authenticated strains of C. gossypii var. cephalosporioides, the taxonomic position of the ramulosis pathogen remains unclear (Hyde et al., 2010; Weir et al., 2012). In this study we tested the hypothesis that the ramulosis pathogen in Brazil is a distinct phylogenetic taxon within the $C$. gloeosporioides species-complex. The possible conspecificity of the ramulosis and the anthracnose pathogens was also assessed.

\section{MATERIAL AND METHODS}

\section{Strains used and morphological characterization}

Twenty-one strains previously identified as representatives of the ramulosis pathogen $C$. gossypii var. cephalosporioides (henceforth called CGC strains), and five strains identified as members of the anthracnose pathogen C. gossypii (CG strains) were obtained from culture collections of two Brazilian agricultural research institutes, the EMBRAPAAlgodão (Campina Grande, Paraíba) and the Instituto Agronômico de Campinas (IAC; Campinas, São Paulo). Such CGC and CG strains were originally isolated from diseased cotton plants or seeds collected in producing areas of four Brazilian states - Bahia, Goiás, Mato Grosso, and São Paulo (Table 1). The preliminary identification of strains was based on their ability to induce disease symptoms on cotton plants in surveys conducted elsewhere. All strains are preserved at $-80^{\circ} \mathrm{C}$ in the Coleção Micológica de Lavras - CML, Universidade Federal de Lavras, Lavras, Brazil.

Cultural and micromorphological traits were evaluated in single spore cultures grown in triplicates on potato dextrose agar (PDA) (Sigma Aldrich), and 2\% malt extract agar (MEA) (Himedia), for seven days at 20, 25 and $30^{\circ} \mathrm{C}$, under constant fluorescent light (Cai et al., 2009). Colony diameters were measured daily and used to calculate the average growth rates, in mm.day ${ }^{-1}$. The size and shape of 30 arbitrarily chosen conidia were measured from each strain cultivated on PDA and MEA at $25^{\circ} \mathrm{C}$. The size and shape of 120 conidia collected from leaves and stems of inoculated plants with symptoms of ramulosis or anthracnose were also measured and recorded. Colony growth rates and conidial lengths were evaluated by means of box-plots (Weir et al., 2012).

\section{DNA extraction, PCR amplification and sequencing}

Single spore cultures prepared with a micromanipulator were grown on PDA for seven days. Mycelia were scraped from the agar surface and genomic DNA extracted with a Wizard Genomic DNA purification kit (Promega) according to the manufacturer's protocol. DNA concentrations were measured with a NanoDrop 2000 (Thermo Fisher Scientific). PCR reactions were performed by using a GoTaq Colorless Master Mix (Promega) in a My Cycler thermal cycler (Bio-Rad). The same primer sets were used for both PCR and sequencing reactions. Portions of the nuclear rDNA including the Internal Transcribed Spacers 1 and 2, and the 5.8S region (ITS) were amplified with primers ITS1Ext (forward; 5'- GTAACAAGGTTTCCGTAGGTG-3') and ITS4Ext (reverse; 5' TTCTTTTCCTCCGCTTATTGATATGC-3'), and cycling conditions: $5 \mathrm{~min}$ at $95^{\circ} \mathrm{C}$, followed by 35 cycles of $30 \mathrm{~s}$ at $94^{\circ} \mathrm{C}, 30 \mathrm{~s}$ at $55^{\circ} \mathrm{C}$ and $2 \mathrm{~min}$ at $72^{\circ} \mathrm{C}$, with a final step of $7 \mathrm{~min}$ at $72^{\circ} \mathrm{C}$ (Talhinhas et al., 2002). A portion of the beta tubulin gene (TUB2) was amplified with primers TB5 (forward; 5'GGTAACCAGATTGGTGCTGCCTT-3') and TB6 (reverse; 5'-GCAGTCGCAGCCCTCAGCCT-3') (Panaccione \& Hanau, 1990) in 35 cycles of PCR reactions. The amplification conditions were the same as those described for the ITS amplification, except for the annealing temperature, which was changed to $62^{\circ} \mathrm{C}$. A fragment of the glyceraldehyde 3-phosphate dehydrogenase gene (GAPDH) was amplified using primers GDF1 (forward; 5'-GCCGTCAACGACCCCTTCATTGA-3') and GDR1 (reverse; 5'-GGGTGGAGTCGTACTTGAGCATGT-3') (Templeton et al. 1992). The cycling conditions were: $5 \mathrm{~min}$ at $94^{\circ} \mathrm{C}$, followed by 34 cycles of $45 \mathrm{~s}$ at $94^{\circ} \mathrm{C}$, $45 \mathrm{~s}$ at $60^{\circ} \mathrm{C}$ and $1 \mathrm{~min}$ at $72^{\circ} \mathrm{C}$, with a final step of 10 min at $72^{\circ} \mathrm{C}$ (Prihastuti et al., 2009). Amplified fragments were cleaned with an Invisorb Fragment Clean Up kit (Stratec Molecular) and sequenced in both directions with a DYEnamic ET Dye terminator cycle sequencing kit (Amersham Biosciences) in a MegaBACE 500 DNA sequencer (Amersham Biosciences) at the Genomics Laboratory, Universidade Federal de Viçosa, Viçosa, Brazil.

\section{Molecular phylogenetics}

Consensus sequences were assembled from forward and reverse sequences using SeqAssem ver. 07/2008 (SequentiX - Digital DNA Processing). Additional sequences of reference strains of the C. gloeosporioides species complex (Weir et al., 2012) were obtained from GenBank (Table 1). No DNA sequence of reference strains of CGC or CG was available for comparisons. Sequences were aligned using MUSCLE as implemented in MEGA 5 
The etiological agent of cotton ramulosis represents a single phylogenetic lineage...

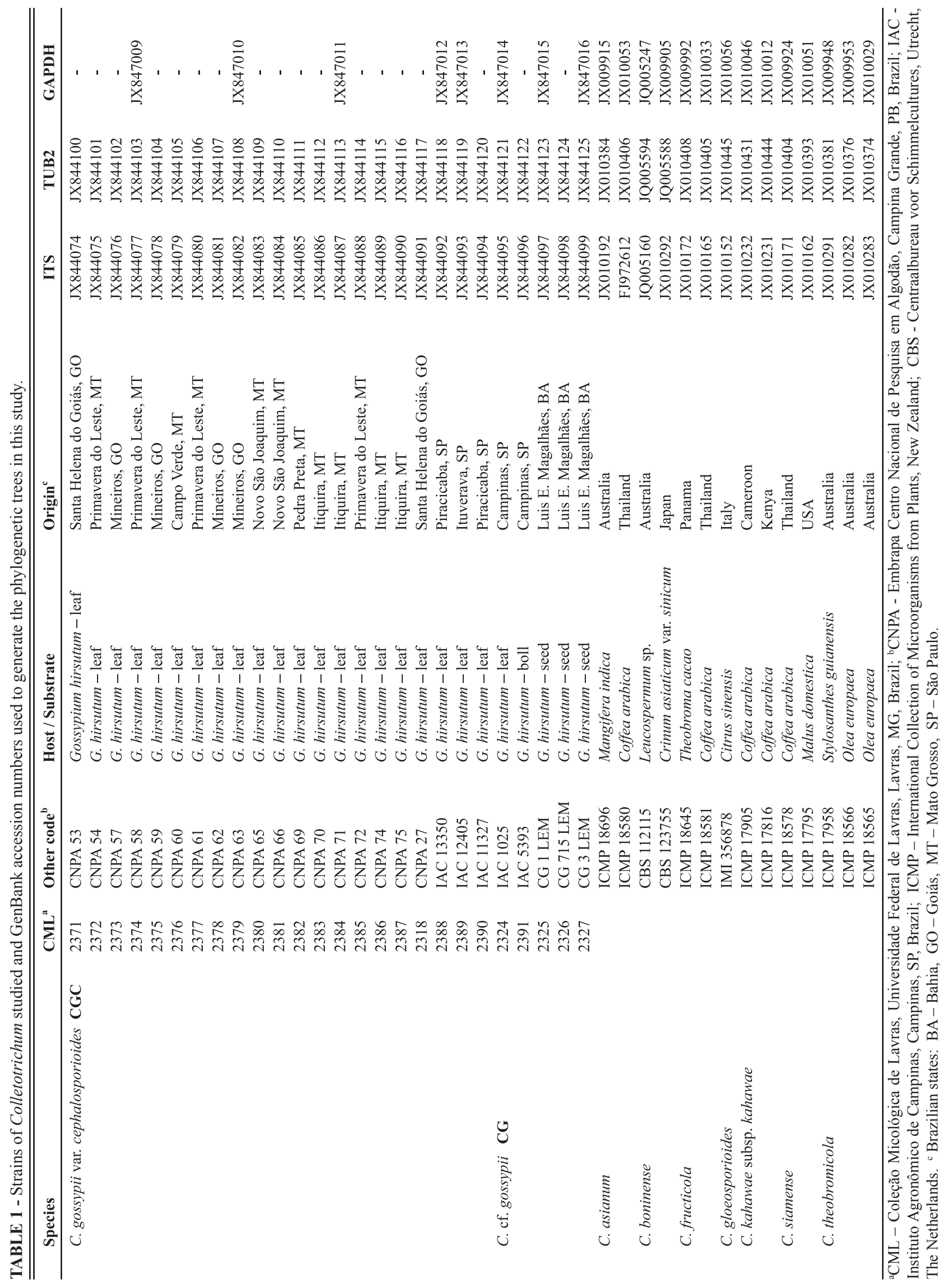


(Tamura et al., 2011). Selection of the best model of DNA sequence evolution for each gene region was done using jModeltest 2 (Darriba et al., 2012). Neighbor Joining phylogenetic trees were constructed for each gene region using MEGA 5. Concatenated datasets (ITS + TUB2 and ITS + TUB2 + GAPDH) were subjected to Bayesian inference of phylogenetic reconstruction using Mr Bayes 3.2 (Ronquist et al., 2012). The estimated models of sequence evolution applied to gene partitions were: K2P + I for ITS and TUB2, and HKY for GAPDH. For each dataset, two independent analyses were run for $1 \times 10^{6}$ generations and sampled every 500 generations. The convergence between the analyses was checked by the values of the standard deviations of the split frequencies and the performance scale reduction factors. Twenty five percent of the trees generated in each analysis were discarded as burn-in. The 50\% majority-rule consensus trees obtained were visualized in FigTree (http://tree.bio. ed.ac.uk/software/figtree/) and edited using InkScape 0.48 (www.inkscape.org). Sequences generated in this study were deposited in GenBank (Table 1).

\section{Pathogenicity tests}

The ability of the studied strains to induce disease symptoms on cotton plants was evaluated by conducting pathogenicity tests in the greenhouse with five strains of the ramulosis pathogen (CGC strains CML 2374, CML 2383, CML 2386, CML 2389, CML 2390), and four strains of the anthracnose pathogen (CG strains CML 2324, CML 2325, CML 2326, CML 2327). One strain of ' $C$. gloeosporioides' (CML 1590) isolated as a leaf endophyte of coffee was included in the pathogenicity trials as a control. The experiments were conducted with the cotton cultivar FiberMax 966 LL (Bayer CropScience).

Each strain was grown on PDA, at $25^{\circ} \mathrm{C}$ under a $12 \mathrm{~h}$ photoperiod, for 10 days to induce sporulation. Conidial suspensions were prepared by adding $3 \mathrm{~mL}$ of sterile distilled water to the plates and gently scraping the mycelia. The resulting suspensions were filtered through a double layer of cheesecloth and the conidial concentration adjusted to $1 \times 10^{6}$. $\mathrm{mL}^{-1}$. Cotton seeds were planted in $5 \mathrm{~L}$ pots containing a mixture of soil, sand, and bovine manure $(2: 1: 1)$. Plants were grown in a greenhouse under $80 \%$ of average relative humidity and temperature of $25 \pm 3^{\circ} \mathrm{C}$, which is near the optimum for the progression of ramulosis (Monteiro et al., 2009). Two seedlings with uniform growth habit were maintained in each pot. Plants were inoculated 32 days after emergence (DAE) in the first experiment, and $52 \mathrm{DAE}$ in the second one. Inoculation was done by spraying conidial suspensions to the point of runoff. After inoculation, the plants were enclosed within plastic bags and kept in a moist environment for 72 hours. Plants sprayed with sterile distilled water served as negative control. Each treatment was composed of four repetitions, with two plants each, arranged in a completely randomized design.
Plants were evaluated weekly for disease symptoms for 105 days. Disease symptoms were assessed using a qualitative scale developed for ramulosis by Araújo et al. (2003): 1, Plants without symptoms; 2, Plants with necrotic spots on young leaves; 3, Plants with necrotic spots on leaves and stems, death of apical meristems, and shortened internodes; 4, Plants with necrotic spots on leaves and stems, shortened internodes and abnormal sprouting of lateral buds (witches' brooms); 5, Plants with necrotic spots on leaves, shortened internodes, witches' brooms and reduced size. The same scale was adapted to assess the intensity of leaf anthracnose, where plants either showed no disease symptoms (score 1 in the scale), or developed necrotic spots on old leaves (score 2).

\section{RESULTS}

\section{Molecular phylogenetics}

DNA sequences of ITS and TUB2 were obtained for all 26 strains used in this study. A Neighbor Joining phylogenetic analysis of ITS sequences, including a comprehensive dataset of reference strains of the C. gloeosporioides species complex (Weir et al., 2012), showed that CGC and CG strains belong to the Colletotrichum theobromicola clade (data not shown).

In the absence of conflicts between the topologies of ITS and TUB2 trees (data not shown), a concatenated dataset was constructed with sequences of both gene regions and used to generate a Bayesian phylogenetic tree with all investigated strains (Figure 1). CGC and CG strains formed two well supported monophyletic groups inside the $C$. theobromicola clade. CG strains formed a sister group with the reference strain ICMP 18567. The remaining reference strains of $C$. theobromicola formed a paraphyletic group with respect to the cotton pathogens.

DNA sequences of GAPDH were generated for a subset of five $\mathrm{CGC}$ and three $\mathrm{CG}$ strains. These sequences were concatenated with ITS and TUB2 sequences to produce a three-gene combined alignment that was subjected to Bayesian phylogenetic analysis. The tree obtained was very similar to the ITS + TUB2 tree, with the ramulosis and anthracnose pathogens forming two phylogenetic lineages within $C$. theobromicola (Figure 2).

\section{Pathogenicity tests}

Two pathogenicity tests were conducted with five CGC and four CG strains inoculated on cotton plants 32 days after emergence (DAE) in the first experiment, and 52 DAE in the second one. Median values of ramulosis and anthracnose intensities obtained in these tests are given in Table 2. All five CGC strains tested induced typical symptoms of ramulosis on cotton plants, including: starshaped perforations on leaves (disease score 2, Figure 3a), death of apical meristems (score 3, Figure 3b-c), development of witches' brooms (score 4, Figure 3d-e), 


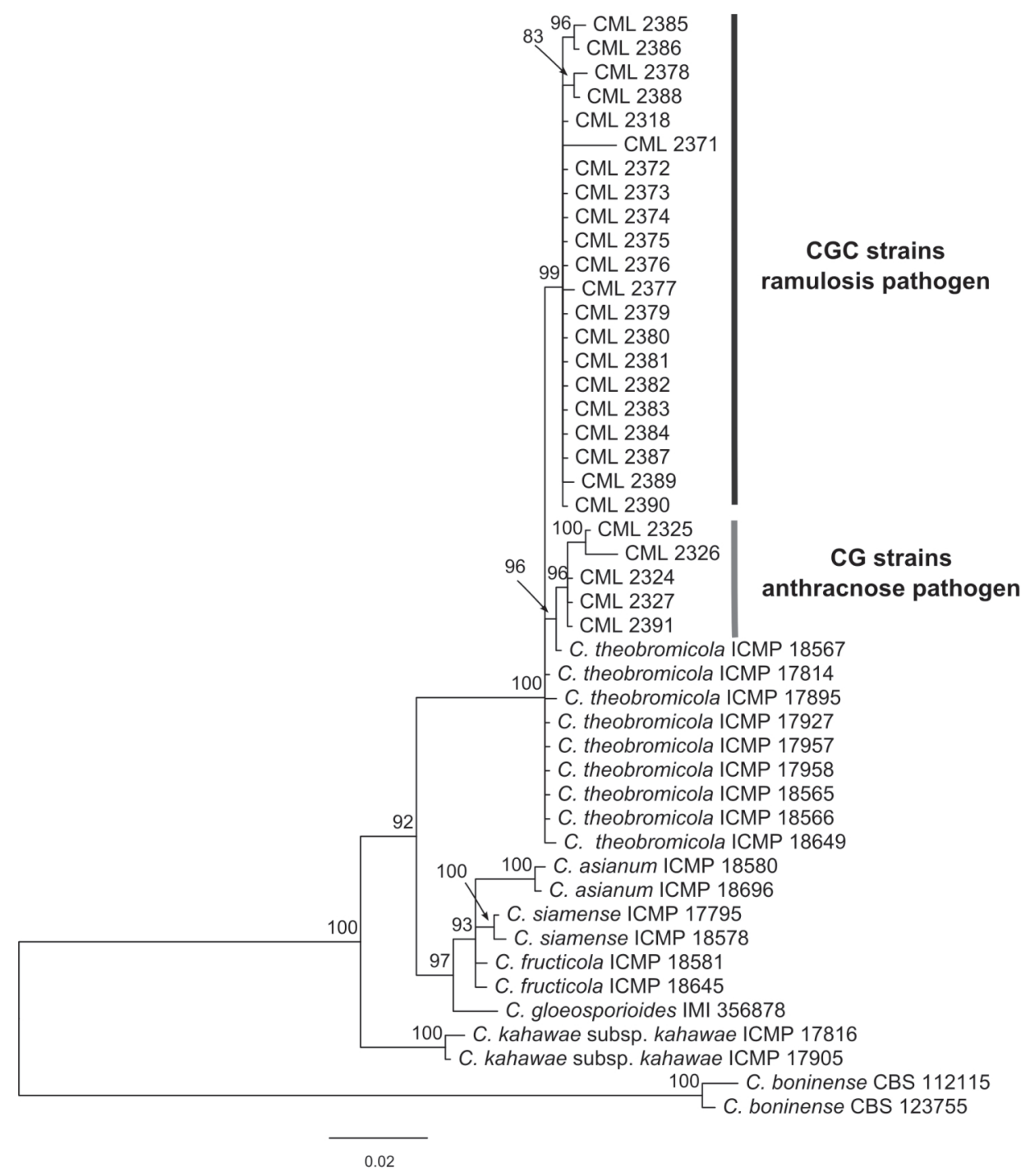

FIGURE 1 - Fifty-percent majority-rule consensus tree based on a Bayesian analysis of the combined ITS-5.8S rDNA and TUB2 gene dataset showing the relationships among CGC, CG, and other members of the Colletotrichum gloeosporioides species complex. $\mathrm{K} 2 \mathrm{P}+\mathrm{I}$ was used as the model of nucleotide substitution. Posterior probability values are displayed on the nodes. All trees were rooted using Colletotrichum boninense (CBS 112115 and CBS 123755) as outgroup.

and reduced plant size (score 5, Figure 3f). Most plants inoculated with the ramulosis pathogens, 32 or $52 \mathrm{DAE}$, exhibited foliar lesions after one week of inoculation (Table 2). Further development of disease symptoms started around 45 days after inoculation (DAI) in both experiments, but was faster and more intense when plants were inoculated $32 \mathrm{DAE}$ (Table 2).

Plants inoculated with CG strains exhibited symptoms of foliar anthracnose around $60 \mathrm{DAI}$, when inoculated $32 \mathrm{DAE}$, and $75 \mathrm{DAI}$, when inoculated 52 DAE (Table 2). Symptoms were observed as brown spots along foliar midribs (Figure 3g). No further development of disease symptoms was observed on plants inoculated with CG strains until the end of the experiment (Table 2). Plants inoculated with CML 1590 and control plants did not develop disease symptoms (Figure $3 \mathrm{~h}$ ).

\section{Cultural and morphological characterization}

Strains of CGC and CG exhibited a diverse set of colony shapes and colors. Colony growth rates between CGC and CG strains overlapped, but CG strains tended to grow faster, especially on PDA (Figure 4). The average growth rates varied from 7 to $14 \mathrm{~mm} /$ day for strains cultivated on MEA, and from 5.5 to $12 \mathrm{~mm} /$ day for those cultivated on 


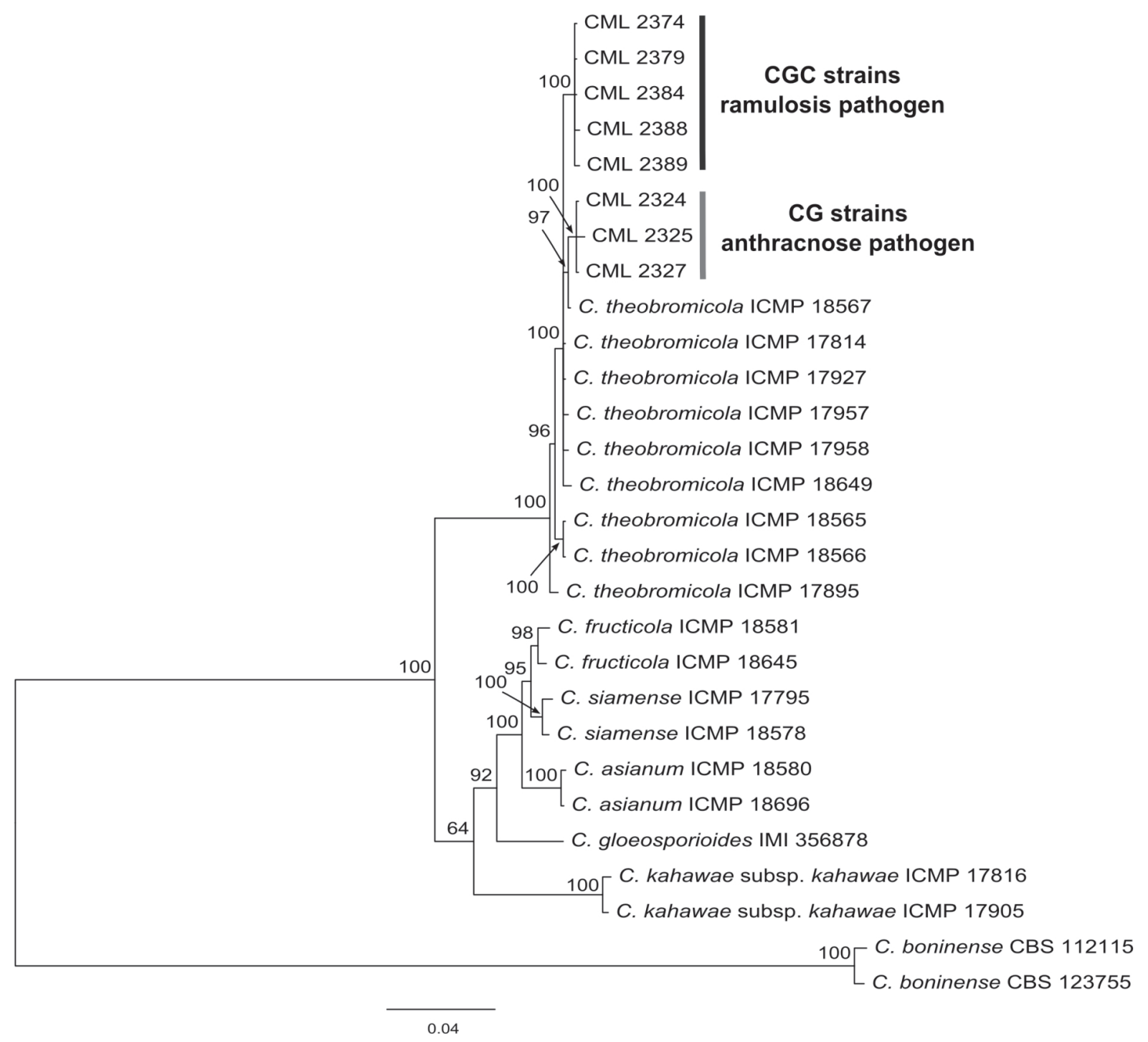

FIGURE 2 - Fifty-percent majority-rule consensus tree based on a Bayesian analysis of the combined ITS-5.8Sr DNA, TUB2 and GAPDH genes dataset showing the relationships among CGC, CG, and other members of the Colletotrichum gloeosporioides species complex. The K2P+I model of nucleotide substitution was applied to ITS and TUB2, and HKY applied to GAPDH. Posterior probability values are displayed on the nodes. All trees were rooted using Colletotrichum boninense (CBS 112115 and CBS 123755) as outgroup.

PDA (Figure 4). The best temperature for mycelial growth was $25^{\circ} \mathrm{C}$ on both culture media. No clear difference in conidial size and shape could be observed between CGC and CG strains. Conidia were straight-cylindrical, tapering towards the base, with widths ranging from 2.5 to $5 \mu \mathrm{m}$. Median conidial length was $12.5 \mu \mathrm{m}$ for strains cultivated on MEA, and $15 \mu \mathrm{m}$ for strains either cultivated on PDA or assessed directly from acervuli on plant leaves (i.e., in vivo).

\section{DISCUSSION}

All 21 strains of Colletotrichum associated with the ramulosis of cotton formed a single phylogenetic lineage within the recently delimited $C$. theobromicola clade of the C. gloeosporioides species complex (Rojas et al., 2010; Weir et al., 2012). The anthracnose pathogens formed another phylogenetic lineage inside the same clade (Figs. 1,2). Bailey et al. (1996) studied two strains of CGC and one strain of CG, collected in Brazil and Bolivia, using short sequences from the rRNA gene cluster (ITS2 and the D2 domain of 28S). The authors found that CGC and $C G$ formed two lineages in the phylogenetic tree, but considered them to be co-specific with C. gloeosporioides due to the small sequence divergence among the studied strains (Bailey et al., 1996). Later, Silva-Mann et al. (2005) successfully distinguished CGC from CG strains, previously discriminated by a pathogenicity test, using AFLP markers. 
The etiological agent of cotton ramulosis represents a single phylogenetic lineage...

TABLE 2 - Median values of disease intensity for ramulosis (CGC strains) and anthracnose (CG strains) pathogens inoculated on cotton plants 32 and 52 days after plant emergence.

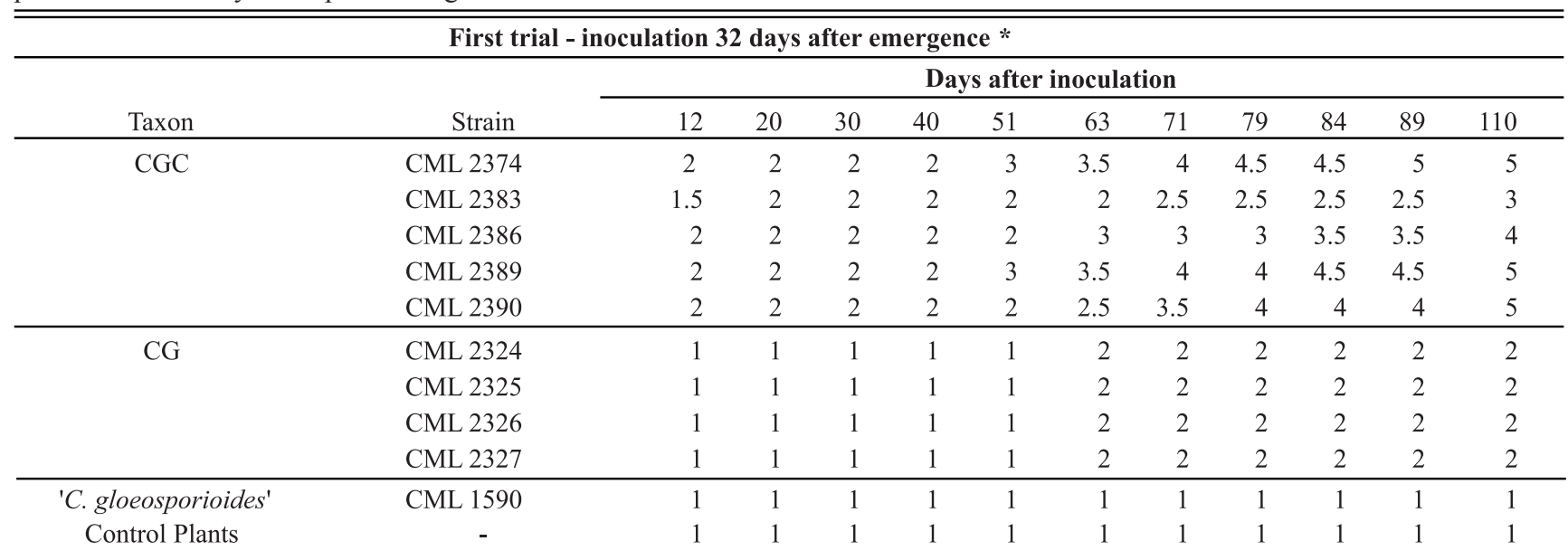

Second trial - inoculation 52 days after emergence *

\begin{tabular}{|c|c|c|c|c|c|c|c|c|c|c|c|c|}
\hline \multirow[b]{2}{*}{ Taxon } & \multirow[b]{2}{*}{ Strain } & \multicolumn{11}{|c|}{ Days after inoculation } \\
\hline & & 7 & 21 & 30 & 40 & 50 & 60 & 72 & 79 & 84 & 90 & 110 \\
\hline \multirow[t]{5}{*}{ CGC } & CML 2374 & 1.5 & 1.5 & 1.5 & 1.5 & 1.5 & 2 & 2 & 2 & 2 & 2 & 2 \\
\hline & CML 2383 & 1.5 & 2 & 2 & 2 & 2 & 2 & 3 & 3 & 3 & 3 & 3 \\
\hline & CML 2386 & 2 & 2 & 2 & 2 & 2 & 2 & 3 & 3 & 3 & 3 & 3 \\
\hline & CML 2389 & 1 & 2 & 2 & 2 & 2 & 3 & 3.5 & 3.5 & 3.5 & 3.5 & 3.5 \\
\hline & CML 2390 & 2 & 2 & 2 & 2 & 2 & 3 & 3.5 & 4 & 4 & 4 & 4 \\
\hline \multirow[t]{4}{*}{ CG } & CML 2324 & 1 & 1 & 1 & 1 & 1 & 1 & 1 & 2 & 2 & 2 & 2 \\
\hline & CML 2325 & 1 & 1 & 1 & 1 & 1 & 1 & 1 & 1 & 2 & 2 & 2 \\
\hline & CML 2326 & 1 & 1 & 1 & 1 & 1 & 1 & 1 & 1.5 & 2 & 2 & 2 \\
\hline & CML 2327 & 1 & 1 & 1 & 1 & 1 & 1 & 1 & 2 & 2 & 2 & 2 \\
\hline 'C. gloeosporioides' & CML 1590 & 1 & 1 & 1 & 1 & 1 & 1 & 1 & 1 & 1 & 1 & 1 \\
\hline Control Plants & - & 1 & 1 & 1 & 1 & 1 & 1 & 1 & 1 & 1 & 1 & 1 \\
\hline
\end{tabular}

"Symptoms were rated according to the following qualitative scale: 1, Plants without symptoms; 2, Plants showing necrotic spots on young leaves; 3, Plants showing necrotic spots on leaves and stems, death of apical meristems and shortened internodes; 4, Plants showing necrotic spots on leaves and stems, shortened internodes and witches; 5, Plants showing necrotic spots on leaves, shortened internodes, witches and size reduction (Araujo et al. 2003).

The five CGC strains used in the pathogenicity tests induced typical symptoms of ramulosis on inoculated cotton plants (Table 2, Figure 3). The intensity of ramulosis was higher in the first experiment when plants were inoculated 32 DAE. Younger plants are more susceptible to ramulosis, since the pathogen is primarily associated with meristems and young tissues (Araújo et al., 2003). CG strains induced late foliar symptoms on inoculated plants that did not spread to other plant organs until the end of the experiments. These results agree with the generally accepted hypothesis that ramulosis and foliar anthracnose of cotton are distinct diseases, caused by two different, but closely related pathogens (Kirkpatrick \& Rothrock 2001; Silva-Mann et al., 2005).

Colletotrichum gossypii var. cephalosporioides is a valid name (Viegas, 1946) that was applied to the etiological agent of cotton ramulosis by Costa and Fraga Jr. (1939), who considered the pathogen to be a more aggressive variety of $C$. gossypii. However, the status of the name $C$. gossypii is uncertain since no type material remains, and no DNA sequence of authenticated strains is available for comparative phylogenetic studies. New collections and the epitypification of C. gossypii in the USA would be necessary to resolve this issue (Hyde et al., 2010). In the present study, the strains associated with ramulosis and anthracnose of cotton in Brazil formed two phylogenetic lineages inside the $C$. theobromicola clade. Cross-inoculation experiments and further phylogenetic analyses using additional genes and more strains belonging to this clade may result in the subdivision of $C$. theobromicola in new species or varieties (Weir et al., 2012). In this context, we opted to not rename the cotton pathogens as $C$. theobromicola at this moment.

Our results provide phylogenetic support to the observation made more than 70 years ago that a single Colletotrichum pathogen is associated with the ramulosis of cotton in Brazil (Costa \& Fraga Jr., 1939). Although the taxonomic and nomenclatural status of this pathogen could not be resolved here, the availability of DNA sequences of 

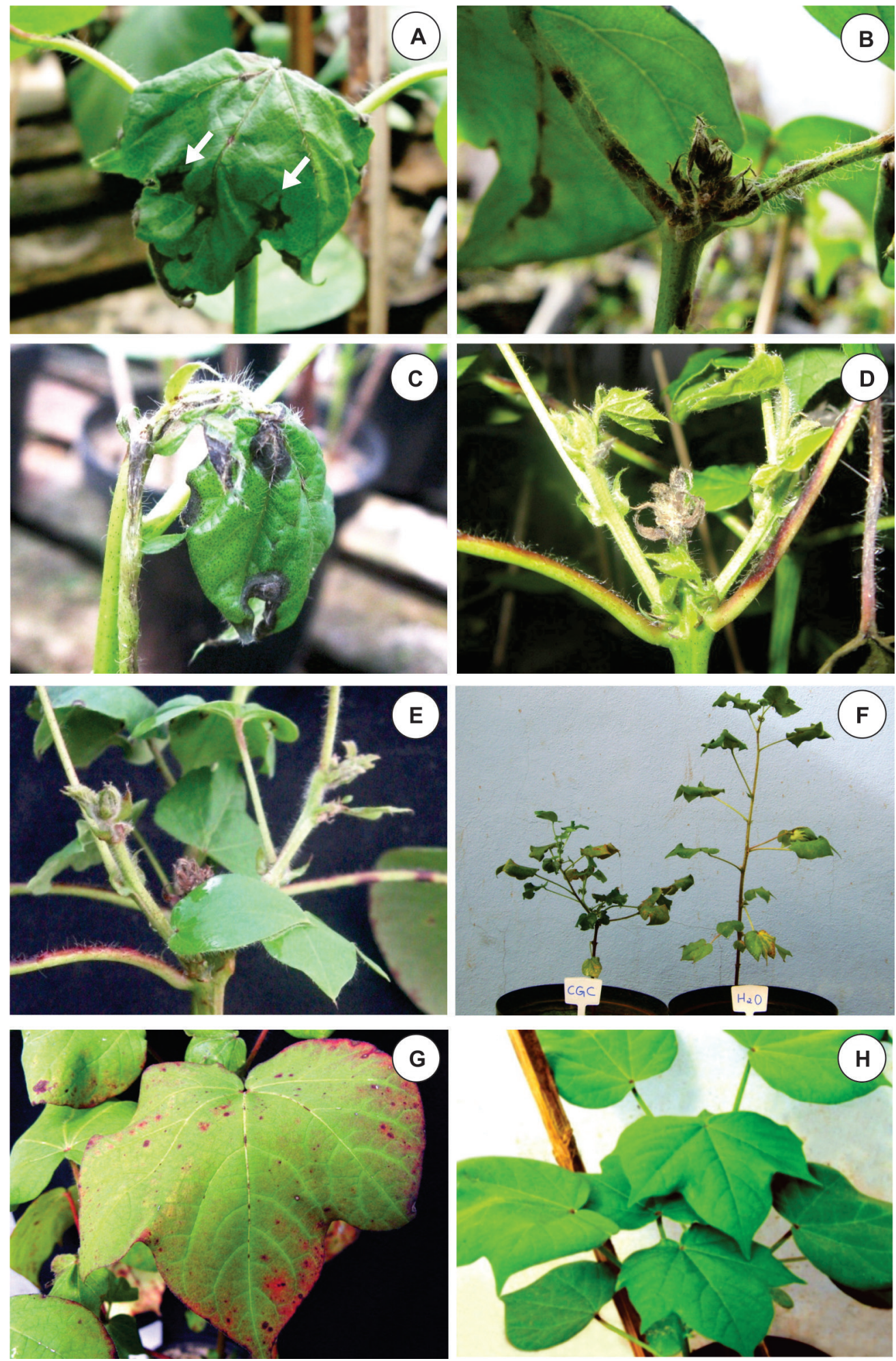

FIGURE 3 - Symptoms of ramulosis and anthracnose observed on cotton plants during the pathogenicity tests. A-F. Symptoms of ramulosis exhibited by plants inoculated with CGC strains: A. Star-shaped foliar necrosis; B-C. Death of apical meristems; D-E. Over sprouting of lateral buds (witches' brooms); F. Plant with reduced size. G. Symptom of leaf anthracnose on a cotton plant inoculated with a CG strain; H. Healthy plant. 

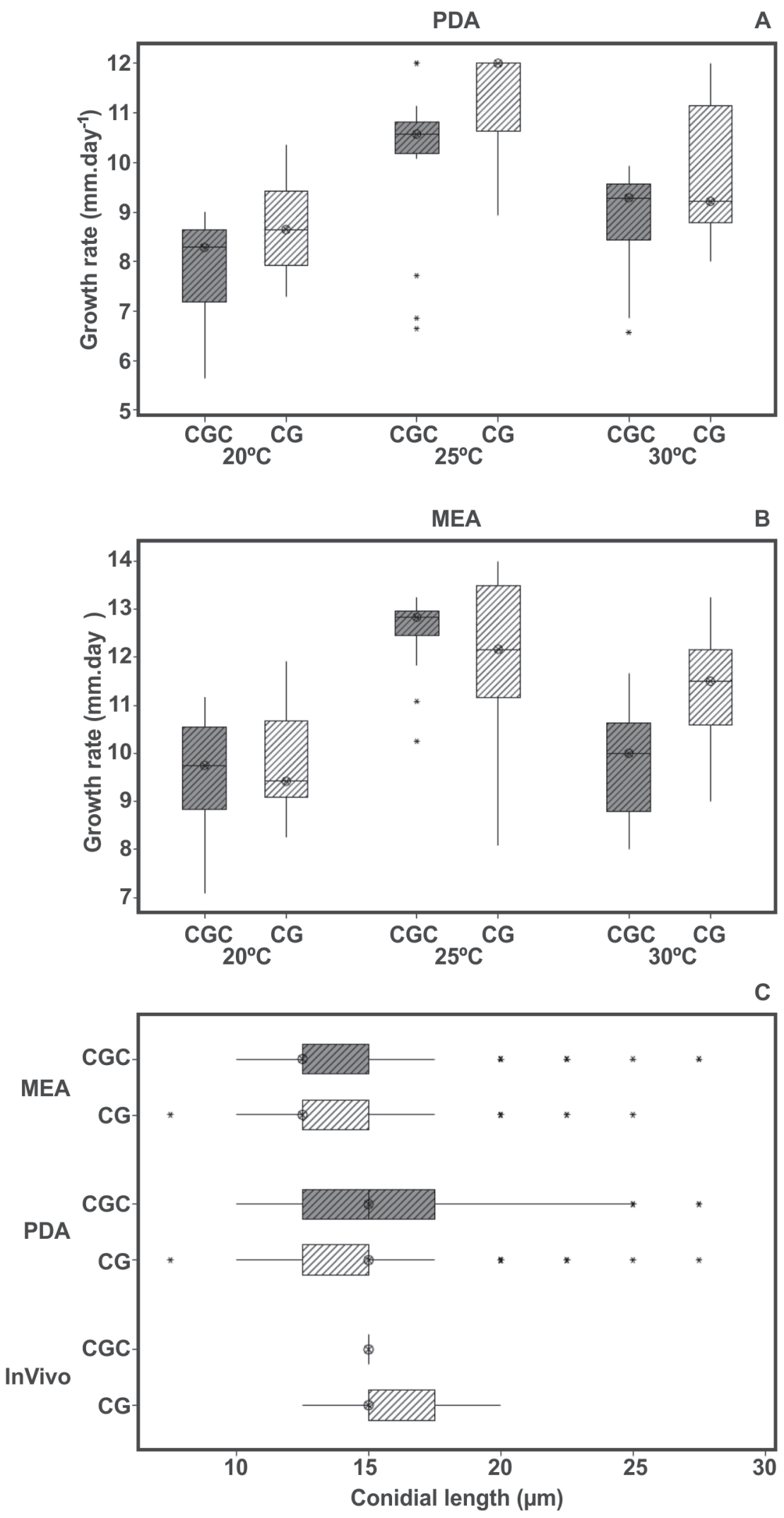

FIGURE 4 - Box-plots showing: A, B. Growth rates (in mm.day ${ }^{-1}$ ) of CGC and $\mathrm{CG}$ strains under three temperatures $\left(20,25\right.$ and $\left.30^{\circ} \mathrm{C}\right)$ on PDA (a) and MEA (b); C. Range of conidial lengths of CGC and CG cultivated on MEA and PDA, or isolated from diseased plants (in vivo). The boxes show the interquartile range, the circles within the boxes represent the median values, and whiskers indicate the lowest and highest non-outlier values. Asterisks indicate outliers. 
authenticated strains with known pathogenicity obtained in this study will be useful for later taxonomic studies and also in developing molecular-based assays for a rapid and reliable detection of CGC strains in cotton seed samples and other plant materials.

\section{ACKNOWLEGEMENTS}

Part of this work received funding from Conselho Nacional de Desenvolvimento Científico e Tecnológico - CNPq (Proc. 559796/2009-9 and 578499/2008-8) and Fundação de Amparo à Pesquisa do Estado de Minas Gerais - FAPEMIG (PPM 0003/2010 and Proc. CAG - 00368/07). LHP, LMA and JCM acknowledge grants provided by Conselho Nacional de Desenvolvimento Científico e Tecnológico - CNPq. Authors are grateful to Wirton Coutinho Macedo, Embrapa Algodão, Campina Grande $\mathrm{PB}$, and Margarida Fumiko Ito from Instituto Agronômico de Campinas IAC, Campinas SP, for providing strains, and Silvia Regina Rodrigues de Paula Ribeiro for technical assistance.

\section{REFERENCES}

Atkinson GF (1891) Anthracnose of cotton. Journal of Mycology $6: 173-178$

Araújo AE, Suassuna ND, Farias FJC, Freire EC (2003) Escalas de notas para avaliação de doenças foliares do algodoeiro. Available at:www.cnpa.embrapa.br/produtos/algodao/publicacoes/ trabalhos_cba4/163.pdf

Bailey JA, Nash C, Morgan LW, O’Connell RJ, TeBeest DO (1996) Molecular taxonomy of Colletotrichum species causing anthracnose on the Malvaceae. Phytopathology 86:1076-1083.

Cai L, Hyde KD, Taylor PWJ, Weir BS, Waller JM, Abang MM, Zhang JZ, Yang YL, Phoulivong S, Liu ZY, Prihastuti H, Shivas RG, McKenzie EHC, Johnston PR (2009) A polyphasic approach for studying Colletotrichum. Fungal Diversity 39:183-204.

Cai L, Udayanga D, Manamgoda DS, Maharachchikumbura SSN, McKenzie EHC, Guo LD, Liu XZ, Bahkali A, Hyde KD (2011) The need to carry out re-inventory of plant pathogenic fungi. Tropical Plant Pathology 36:205-213.

Cannon PF, Damm U, Johnston PR, Weir BS (2012) Colletotrichum - current status and future directions. Studies in Mycology 73:181213.

Costa AS, Fraga Jr C (1937) Superbrotamento ou ramulose do algodoeiro. Revista de Agricultura 12:249-259.

Costa AS, Fraga Jr C (1939) Sobre a natureza de ramulose ou superbrotamento do algodoeiro. Jornal de Agronomia 2:151-160.

Darriba D, Taboada GL, Doallo R, Posada D (2012) jModelTest 2: more models, new heuristics and parallel computing. Nature Methods 9:772-772.

EPPO (2009) Datasheets on quarantine pests. Glomerella gossypii. EPPO quarantine pest. Available at: www.eppo.org/ QUARANTINE/fungi/Glomerella_gossypii/GLOMG O_ds.pdf.

Hyde KD, Cai L, Cannon PF, Crouch JA, Crous PW, Damm
U, Goodwin PH, Chen H, Johnston PR, Jones EBG, Liu ZY, McKenzie E HC, Moriwaki J, Noireung P, Pennycook SR, Pfenning LH, Prihastuti H, Sato T, Shivas RG, Tan YP, Taylor PWJ, Weir BS, Yang YL, Zhang JZ (2010) Colletotrichum names in current use. Fungal Diversity 39:147-183.

Kirkpatrick TL, Rothrock CS (2001) Compendium of Cotton Diseases. $2^{\text {nd }}$ Ed. St. Paul, MN, USA. ASP Press.

Lima EF, Carvalho JMFC, Carvalho LP, Costa JN (1985) Transporte e transmissibilidade de Colletotrichum gossypii var. cephalosporioides através da semente do algodoeiro. Fitopatologia Brasileira 10:99-109.

MAPA (2005) Sistema integrado de legislação- Instrução Normativa MAPA 25/2005-Padrões para produção e comercialização de algodão. Available at: www.lassul.com.br/ v1/upload/downloads/file_5.pdf.

Malaguti G (1955) La escobilla del algodon en Venezuela. Agronomia Tropical 5:73-86.

Mathieson JT, Mangano V (1985) Ramulose, a new cotton disease in Paraguay caused by Colletotrichum gossypii var. cephalosporioides. Summa Phytopathologica 11:115-118.

Monteiro JEBA, Sentelhas PC, Gleason ML, Esker PD, Chiavegato EJ (2009) Development of ramulosis disease of cotton under controlled environment and field conditions. Phytopathology 99:659-665.

Panaccione DG, Hanau RM (1990) Characterization of two divergent $\beta$-tubulin genes from Colletotrichum graminicola. Gene 86:163-170.

Prihastuti H, Cai L, Chen H, Hyde KD (2009) Characterization of Colletotrichum species associated with coffee berries in Chiang Mai, Thailand. Fungal Diversity 39:89-109.

Rojas EI, Rehner SA, Samuels GJ, Van Bael SA, Herre EA, Cannon P, Chen R, Pang J, Wang R, Zhang Y, Peng YQ, Sha $\mathrm{T}$ (2010) Colletotrichum gloeosporioides s.l. associated with Theobroma cacao and other plants in Panama: multilocus phylogenies distinguish host-associated pathogens from asymptomatic endophytes. Mycologia 102:1318-1338.

Ronquist F, Teslenko M, van der Mark P, Ayres DL, Darling A, Höhna S, Larget B, Liu L, Suchard MA, Huelsenbeck JP (2012) MrBayes 3.2: efficient Bayesian phylogenetic inference and model choice across a large model space. Systematic Biology 61:539-542.

Saran PE (2009) Manual de Doenças do Algodoeiro. FMC Agricultural Products. Available at: www.fmcdireto.com.br/ portal/manuais/doencas_algodoeiro/index.html

Silva-Mann R, Vieira MGC, Machado JC, Bernardino Filho JR, Salgado KCC, Stevens MR (2005) AFLP markers differentiate Colletotrichum gossypii from C. gossypii var. cephalosporioides. Fitopatologia Brasileira 30:169-172.

Southworth EA (1890) Anthracnose of cotton. Journal of Mycology 6:100-105.

Talhinhas P, Sreenivasaprasad S, Neves-Martins J, Oliveira H (2002) Genetic and morphological characterization of Colletotrichum acutatum causing anthracnose of lupins. Phytopathology 92:986-996.

Tamura K, Peterson D, Peterson N, Stecher G, Nei M, Kumar S (2011) MEGA5: Molecular Evolutionary Genetics 
Analysis using maximum likelihood, evolutionary distance, and maximum parsimony methods. Molecular Biology and Evolution 28:2731-2739.

Tanaka MAS, Menten JOM, Machado JC (1996) Hábito de crescimento de Colletotrichum gossypii e C. gossypii var. cephalosporioides em sementes de algodoeiro. Bragantia 55:95-104.

Templeton MD, Rikkerink EHA, Solon SL, Crowhurt RN (1992)
Cloning and molecular characterization the glyceraldehyde-3phosphate dehydrogenase-encoding gene and cDNA from the plant pathogenic fungus Glomerella cingulata. Gene 122:225-230.

Viegas AP (1946) Alguns fungos do Brasil XII. Fungi Imperfecti Melanconiales. Bragantia 6:1-37.

Weir BS, Johnston PR, Damm U (2012) The Colletotrichum gloeosporioides species complex. Studies in Mycology 73:115180.

TPP-2014-0019

Submitted: 3 February 2014

Revisions requested: 6 March 2014

Accepted: 30 April 2014

Section Editor: Meike Piepenbring 